\title{
Intraspinal and Urogenital Abnormalities in Infants with Sacral Cutaneous Lesions
}

Yu Seon Kim, M.D., Da Hee Jin, M.D., Jeong Hee Shin, M.D., Eun Hee Lee, M.D., Byung Min Choi, M.D., Young Sook Hong, M.D., Ph.D., and Bo Gyeong Je, M.D.*

Departments of Pediatrics and Radiology*, Korea University College of Medicine, Seoul, Korea

\section{ABSTRACT}

Purpose: Sacral cutaneous lesions, such as dimples and hairy patches, may be associated with occult spinal dysraphism and urogenital abnormalities. This study aim to delineate high risk infants who need early screening for intraspinal and urogenital abnormalities by identifying the association between cutaneous lesions and combined abnormalities.

Methods: Sacral ultrasonography was performed in 777 infants with sacral cutaneous lesions from January 2010 to July 2014. Of these, 317 infants underwent abdominal ultrasonography for urogenital abnormalities. We reviewed the patient's medical records and radiographic findings retrospectively.

Results: Of the 777 infants, abnormal intraspinal findings such as tethered cord or meningocele were reported in 26 (3.4\%). Sixteen of these 26 patients with abnormal findings underwent follow-up ultrasonography or MRI; 4 infants were diagnosed with lipomeningomyelocele through MRI, and 1 infant underwent a neurosurgical procedure. Among the 317 infants who underwent abdominal ultrasonography, 78 infants (24.6\%) had congenital hydronephrosis and 8 infants (2.5\%) had other urogenital abnormalities including duplication of kidney, vesicoureteral reflux, horseshoe kidney, renal cyst, or multicystic dysplastic kidney. Urogenital abnormalities were more common in patients with sacral dimples associated with hair or deviated gluteal folds than in those with simple dimples (OR 3.24 and 8.88; $P=0.007$ and $P=0.001$, respectively).

Conclusion: Midline sacral cutaneous lesions may be associated with occult spinal dysraphism and urogenital abnormalities. To detect intraspinal lesions, ultrasonography is recommended for infants with sacral cutaneous lesions. Likewise, infants with sacral dimples associated with either hair or deviated gluteal folds, should be evaluated via abdominal ultrasonography to assess for combined urogenital abnormalities.

Key Words: Occult spinal dysraphism, Cutaneous lesions, Urogenital abnormality, Ultrasonography
Received: 29 September 2014

Revised: 17 October 2014

Accepted: 29 October 2014

Correspondence to:

Young Sook Hong, M.D., Ph.D.

Department of Pediatrics,

Korea University Guro Hospital, 148 Gurodong-ro, Guro-Gu,

Seoul 152-703, Korea

Tel: +82-2-2626-1229

Fax: +82-2-2626-1249

E-mail: hongys@korea.ac.kr

This article was presented as a poster presentation at the 19th annual autumn meeting of the Korean Society of Neonatology.

Copyright(c)

By Korean Society of Neonatology.

All right reserved.

This is an Open-Access article distributed under the terms of the Creative Commons Attribution Non-Commercial License (http://creativecommons.org/licenses/ by-nc/3.0), which permits unrestricted non-commercial use, distribution, and reproduction in any medium, provided the original work is properly cited. 
서론

영아에서 천골부에 피부 함몰(sacral dimple), 털 등의 피부 병 변이 관찰되는 경우, 잠재 척추 파열증(occult spinal dysraphism) 같은 기형과 연관되어 있는 경우가 있다. 잠재 척추 파열증은 임 신 나이 3-4주에 닫혀야 할 신경관이 제대로 닫히지 못하여 발생 하는 선천 기형인 신경관 결손의 하나로, 병변 부위가 피부로 덮 여 있어서 신경 조직이 노출되지 않는 경우를 말한다. 아직까지 정확한 원인은 밝혀져 있지 않으나 방사선, 약물, 영양결핍 및 유 전적 인자가 관여하는 것으로 알려져 있다1,2). 여기에는 잠재 이 분 척추(spina bifida occulta), 수막 탈출증(meningocele), 계류 척수(tethered cord) 등의 질환이 포함된다. 잠재 척추 파열증은 대부분 임상증상이 나타나지 않지만, 피부 병변 외에 선천적으로 비정상적인 척수 및 신경 뿌리에 의한 상위운동신경세포 기능 이 상, 계류 척수에 의한 하위운동신경세포 기능 이상 등 동반된 기 형에 의한 증상을 나타낼 수 있다. 하지만 이런 증상들도 영아들 이 기거나 걷기 전까지는 임상적으로 나타나지 않을 수 있어 진 단이 늦어지는 경우가 발생한다3,4). 그러므로 천골부 피부 병변이 보이는 영아에서 신경학적 이상이 나타날 수 있는 잠재 척추 파 열증을 조기에 발견하여 치료하는 것이 중요하다3-5).

척추 파열증은 외배엽, 중배엽과 신경외배엽의 발달과정 이상 에서 유래된 모든 결손을 포함하므로 피부 병변 이외에 중추신경 계, 골격계, 요로계 기능에도 영향을 줄 수 있다2,6) 잠재 척추 파 열증에서는 수신증, 일측성 신장 무형성, 마제신(horseshoe kidney) 등의 요로계 이상이 동반된다고 알려져 있는데, 이들은 출 생시 잠재 척추 파열증 환자의 5-25\%에서 나타나고 이중 3\%는 수신증과 함께 신기능이 저하되어 있는 것으로 보고되고 있다2). 그러므로 동반된 요로계 기형 및 기능 이상을 조기에 확인할 필 요가 있다. 지금까지 천골부의 피부 병변과 동반된 척추 질환에 대한 연구는 있으나 요로계 질환에 대한 국내 보고는 없었다.

본 연구에서는 외배엽 발생 이상인 천골부 피부 병변을 보이는 영아에서 천골부 및 복부 초음파 검사를 시행하여 외배엽 발생 이상인 잠재 척추 파열증 등의 신경계 질환뿐 아니라 중배엽 발 생 이상인 요로계 질환 동반여부를 파악함으로써 고위험 영아를 선별하여 조기에 잠재 척추 파열증, 요로계 질환 등을 발견하는데 도움을 주고자 하였다.

\section{대상 및 방법}

\section{1. 대상}

본 연구는 2010년 1월부터 2014년 7월까지 고려대학교 의료원
소아청소년과에서 피부 함몰, 털, 피하종괴, 모반, 둔근 주름의 만 곡 등 천골부 피부 병변이 관찰되어 천골부 초음파 검사를 시행 하였던 환자 777 명을 대상으로 하였다. 이들 중 317 명은 요로계 질환 동반 유무를 관찰하기 위하여 복부 초음파 검사를 동시에 시행하였다.

\section{2. 방법}

의무기록을 통해서 초음파 검사 시행 당시의 연령, 성별 및 초 음파 영상 소견, 이후 최대 17 개월간의 추적관찰 결과, 수술 시행 여부를 후향적으로 분석하였다. 천골부 피부 함몰은 함몰이 항문 으로부터 $2.5 \mathrm{~cm}$ 상방에 위치하고 깊이 $5 \mathrm{~mm}$ 이상인 경우로 정 의하였다. 천골부 초음파 검사는 Philips L12-5MHz linear probe 를 사용하여 엎드린 자세에서 시행하였다. 초음파 검사시 종말 뇌 실(ventriculus terminalis)과 척수 종말끈 낭종(filar cyst)이 관찰 된 경우는 정상 변형 소견으로 보았다 ${ }^{7-9)}$. 척수 종말끈 비후(thick filum)는 척수 종말끈(terminal filum)이 $2 \mathrm{~mm}$ 이상인 경우로 정 의하였고, 낮은 위치의 척수 원추(low conus medullaris)는 척수 원추의 위치가 L2-L3 보다 낮은 경우로 정의하였다3). 추적검사는 초음파 검사 또는 자기공명영상검사(magnetic resonance imaging, MRI)로 시행하였다.

복부 초음파 검사에서는 수신증 및 다른 요로계 질환 동반 유무 를 확인하였고 이상 소견이 관찰된 경우 초음파 검사, 자기공명영 상 요로조영술(MRI urography), 경정맥 신우 조영술(intravenous pyelography), 배뇨 방광 요도 조영술(voiding cystourethrography) 같은 추적검사를 통해 경과를 관찰하였다.

수집된 자료는 SPSS statistic software (SPSS Inc., Chicago, IL, USA)를 이용하여 이분형 로지스틱 회귀분석(binary logistic regression)을 하였고, $P<0.05$ 인 경우 통계학적으로 유의하다고 판정하였다.

결과

\section{1. 연령 분포 및 피부 병변}

대상 환자 총 777 명 중 남아는 370 명, 여아는 407명이었다. 천 골부 초음파 검사 시행 당시 연령 분포를 살펴보면, 생후 28 일 이 하 613명(78.9\%), 생후 29-60일 84명(10.8\%), 생후 61-90일 26 명(3.3\%), 생후 91일 이상 54명(7.0\%)으로 대부분 신생아기에 신체 검진을 통해 천골부 피부 병변을 발견하고 초음파 검사를 시행하였다.

천골부 피부 병변으로는 피부 함몰, 털, 피하 종괴, 모반(nevi) 혹은 탈색소성 병변(depigmented lesion), 피부 굴길(sinus tract), 쥐젖(skin tag), 소개구부(porus), 둔근 주름의 만곡(deviated 
gluteal fold, DGF)이 있었다(Figure 1). 전체 환자 777명 중 단일 병변만 있는 경우는 698명(89.8\%)이었고, 두 개 이상의 복합 병 변이 동반되어 있는 경우는 79 명(10.2\%)이었다. 빈도를 살펴보 면 피부 함몰만 있는 경우가 692명(89.0\%)으로 가장 많았고, 털 과 피부 함몰이 있는 경우 58 명 (7.4\%), 피부 함몰과 함께 둔근 주 름의 만곡이 있는 경우 14 명 $(1.8 \%)$ 순이었다(Table 1$)$.

\section{2. 척수 이상 소견}

\section{1) 이상 소견}

초음파 검사상 비정상적인 소견을 보인 경우는 26명(3.4\%)으 로 계류 척수 9 명 $(1.2 \%)$, 낮은 위치의 척수 원추 10 명(1.3\%), 척 수 종말끈 비후 2 명 $(0.3 \%)$, 척수 종말끈 내의 지방 1 명 $(0.1 \%)$, 수 막 탈출증 4 명 $(0.5 \%)$ 이었다(Table 2). 이상 소견을 보인 26명 중
단일 피부 병변은 20 명이고 복합 피부 병변은 6 명이었다. 단일 병 변별 이상 소견을 보면 피부 함몰만 있는 692 명 중 19명에서 이 상 소견이 발견되었는데 계류 척수 8 명, 낮은 위치의 척수 원추 7 명, 척수 종말끈 비후 2 명, 척수 종말끈 내의 지방과 수막 탈출증 각 1 명이었다. 피하 종괴 4 명 중에서는 1 명에서 수막 탈출증이 관 찰되었다. 두 개 이상의 복합 병변이 있는 환자 79명 중 6명(7.6 $\%)$ 에서 이상 소견이 관찰되었는데 피부 함몰과 털이 동반된 경 우 2 명, 피부 함몰과 둔근 주름의 만곡이 있는 경우 1 명, 피하종괴 와 탈색소성 병변이 있는 경우 1 명, 피부 함몰과 피하 종괴가 있 는 경우 1 명이었고 네 가지 병변(피부 함몰, 털, 둔근 주름의 만곡, 피하 종괴)이 동반되어 있는 경우 1 명에서 낮은 위치의 척수 원 추, 계류 척수, 수막 탈출증이 관찰되었다(Table 1). 단일 병변과 복합 병변을 비교했을 때 척수 이상의 동반은 복합 병변에서 높
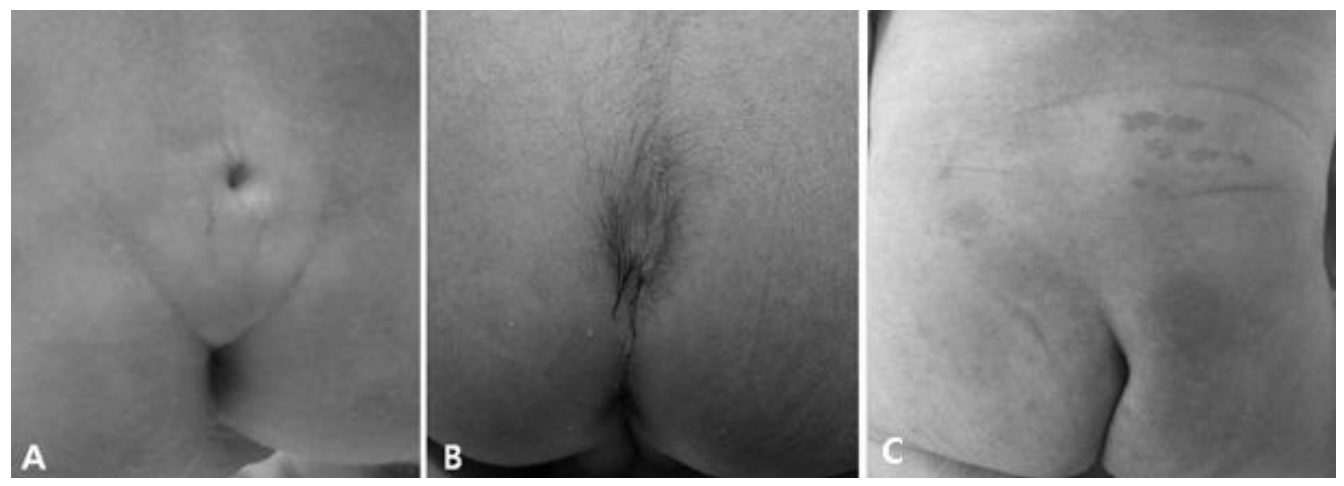

Figure 1. Clinical features of midline sacral cutaneous lesions. (A) Cutaneous dimple with porus, (B) Cutaneous dimple with hair (C) Cutaneous dimple with deviated gluteal fold.

Table 1. Sacral Cutaneous Lesions and Associated Intraspinal Abnormalities in Sacral Ultrasonography

\begin{tabular}{lccc}
\hline Sacral cutaneous lesion & No. of cases (\%) & $\begin{array}{c}\text { No. of patients with } \\
\text { intraspinal abnormalities }\end{array}$ & Intraspinal abnormalities (n) \\
Single lesion & $698(89.8)$ & 20 & Tethered cord (8), Low conus (7), Thick filum (2), Fat \\
Dimple & $692(89.0)$ & 19 & in filum (1), Meningocele (1) \\
Mass & $4(0.5)$ & 1 & Meningocele (1) \\
Sinus tract & $1(0.1)$ & 0 & \\
Skin tag & $1(0.1)$ & 0 & \\
Multiple lesions & $79(10.2)$ & 6 & Low conus (2) \\
Dimple+Hair & $58(7.4)$ & 2 & Low conus (1) \\
Dimple+DGF & $14(1.8)$ & 1 & Teningocele (1) \\
Dimple+Porus & $1(0.1)$ & 0 & \\
Dimple+Mass & $2(0.3)$ & 1 & Meningocele (1) \\
Mass+Depigmentation & $2(0.3)$ & 1 & \\
Dimple+Nevi & $1(0.1)$ & 0 & 1 \\
Dimple+Hair+DGF+Mass & $1(0.1)$ & 26 &
\end{tabular}

Abbreviations: No, number; DGF, deviated gluteal fold. 
았으나 의미 있는 차이는 없었다(교차비 각각 $0.46,2.18 ; P=$ 0.129). 피부 병변 중 빈도가 높았던 세 군, 즉 피부 함몰만 있는 군, 털과 피부함몰이 있는 군, 주름의 만곡과 피부 함몰이 있는 군 간의 척수 이상 소견은 피부 함몰만 있는 군에서 의미 있게 낮았 다(교차비 0.32; 95\% 신뢰구간 0.13-0.77; $P=0.012$ ).

2) 추적 관찰 소견

척수 이상 소견이 관찰된 환자 26 명 중 추적검사를 시행한 경 우는 16 명으로 계류 척수 6 명, 낮은 위치의 척수 원추 5 명, 척수 종말끈 내의 지방 1 명, 수막 탈출증 4 명이었다. 초음파 검사상 계 류 척수가 관찰되었던 환자 중 1 명은 MRI상 종사내 섬유지방종 (filar fibrolipoma)과 이로 인한 낮은 위치의 척수 원추가 동반된 소견을 보였고, 5 명은 MRI에서도 계류 척수가 관찰되었다. 초음 파 검사상 척수 종말끈 내의 지방이 있었던 환자 1 명은 MRI상 염 증성 지주막염(inflammatory arachnoiditis)이 관찰되었다. 수막 탈출증이 있었던 4명은 MRI 추적검사상 지방척수수막류(lipomeningomyelocele)와 함께 계류 척수, 천미부 척추 파열증 (sacral dysraphism), 척추 형성이상 등이 동반되어 있었고 이 중 1 명은 신경외과적 수술을 시행하였다. 정상변형으로 분류한 종 말 뇌실과 척수 종말끈 낭종이 있던 환자 751 명 중 80 명에서 추 적검사를 실시한 결과 척수 종말끈 낭종 환자 1 명에서 $\mathrm{MRI}$ 상 부 분 척수내수종(focal hydromyelia)이 관찰되어 경과관찰 중이다 (Table 2).

천골부 초음파 검사 결과, 정상 또는 정상변형 소견을 보인 경 우는 전체 777명 중 751명(96.6\%)으로 정상 582명(74.9\%), 종말
뇌실 127명(16.3\%), 척수 종말끈 낭종 42명(5.4\%)이었다.

\section{3. 요로계 이상 소견}

본 연구 대상 환자 777명 중 317명(남아 166명, 여아 151명)은 천골부 초음파 검사시 수신증 및 다른 요로계 질환 동반 유무를 확인하기 위해 복부 초음파 검사를 동시에 시행하였다. 검사 시행 당시의 나이 분포는 생후 3 일 이내 147명(46.4\%), 4-28일 106명 (33.4\%), 29-60일 30명(9.5\%), 61-90일 9명(2.8\%), 91일 이상 25명 (7.9\%)이었다. 복부 초음파 검사 대상 환자들의 피부 병변 분포를 보면 피부 함몰이 있는 경우가 278명(87.7\%)으로 가장 많았고, 피부 함몰과 털이 동반된 경우 23명 $(7.3 \%)$, 피부 함몰과 둔근 주름의 만곡이 동반된 경우 12 명 $(3.8 \%)$, 쥐젖 1 명, 피부 함 몰과 피하 종괴가 동반된 경우 1 명, 피부 함몰과 소개구부가 동반 된 경우 1 명, 피부 함몰과 털, 둔근 주름의 만곡, 피하 종괴가 동반 된 경우 1 명이었다.

이상 소견이 관찰된 경우는 총 86명(27.1\%)이었고, 이 중 수신 증만 관찰된 경우는 78명(24.6\%)이었다. 피부 함몰만 있는 환자 278 명 중에서는 수신증 57 명 이외에도 동반된 질환으로 우측 신 장 중복 2명, 양측 방광요관역류(VUR, grade 5/4) 1명, 마제신 1 명, 다낭 형성 이상 신장(multicystic dysplastic kidney, MCDK) 1 명, 신장 낭종(renal cyst) 1 명이 있었다. 피부 함몰과 둔근 주름의 만곡이 동반된 12 명 중에서는 수신증 8 명과 신장 낭종 1 명이 있 었다. 피부 함몰과 털, 둔근 주름의 만곡, 피하 종괴가 동반된 1 명 에서는 마제신이 관찰되었다(Table 3).

Table 2. Sacral Ultrasonography and Further Imaging Study Findings in 777 Patients with Sacral Cutaneous Lesions

\begin{tabular}{|c|c|c|c|}
\hline & No. of cases & No. of F/U & F/U findings (n) \\
\hline Tethered cord & 9 & 6 & $\begin{array}{l}\text { US \& MRI (1): Low conus with Filar fibrolipoma } \\
\text { MRI (5): Tethered cord (5) }\end{array}$ \\
\hline Low conus medullaris & 10 & 5 & US (5): Normal (2), Not changed (3) \\
\hline Thick filum & 2 & 0 & \\
\hline Fat in filum & 1 & 1 & MRI (1): Inflammatory arachnoiditis \\
\hline Meningocele & 4 & 4 & $\begin{array}{l}\text { MRI (4): Tethered cord, Lipomeningomyelocele }(1)^{*} \text {, Sacral dysraphism, } \\
\text { Lipomeningomyelocele (1), Tethered cord, Terminal syrinx, Lipomeningocele } \\
\text { (1), Lipomeningomyelocele, Butterfly vertebrae at T12, Tethered cord, Sacral } \\
\text { deformity (1) }\end{array}$ \\
\hline Ventriculus terminalis & 127 & 66 & $\begin{array}{l}\text { US (66): Normal (26), Not changed (29) } \\
\text { Size increased (5), Size decreased (6) }\end{array}$ \\
\hline Filar cyst & 42 & 14 & $\begin{array}{l}\text { US (10): Normal (3), Not changed (5), Decreased (2) } \\
\text { MRI (2): Regression (1), Focal hydromyelia (1) } \\
\text { US \& MRI (2): Normal (1), Filar cyst (1) }\end{array}$ \\
\hline Normal & 582 & 0 & \\
\hline Total & 777 & 96 & \\
\hline
\end{tabular}

Abbreviations: No, number; F/U, follow-up; US, ultrasonography; MRI, magnetic resonance imaging.

*The infant had sacral dimple with mass over the midline sacral region, and underwent neurosurgical procedure. 
Table 3. Abdominal Ultrasonographic Findings in 317 Patients with Sacral Cutaneous Lesions

\begin{tabular}{|c|c|c|c|c|}
\hline \multirow{2}{*}{ Sacral cutaneous lesion } & \multirow{2}{*}{ Number } & \multicolumn{3}{|c|}{ Urogenital abnormalities (n) } \\
\hline & & No. of cases & Hydronephrosis & Others \\
\hline \multirow[t]{2}{*}{ Dimple } & 278 & 63 & 57 & $\begin{array}{l}\text { Duplication of Kidney (2), Bilateral VUR,Gr 5/4 } \\
\text { (1), Horseshoe kidney (1)*, Unilateral MCDK (1) }\end{array}$ \\
\hline & & & & Renal cyst (1) \\
\hline Skin tag & 1 & 0 & & \\
\hline Dimple+DGF & 12 & 9 & 8 & Renal cyst (1) \\
\hline Dimple+Porus & 1 & 1 & 1 & \\
\hline Dimple+Hair+DGF+Mass & 1 & 1 & & Horseshoe kidney $(1)^{\dagger}$ \\
\hline Total & 317 & $86(27.1 \%)$ & $78(24.6 \%)$ & 8 \\
\hline
\end{tabular}

Abbreviations: DGF, deviated gluteal fold; VUR, vesicoureteral reflux; MCDK, multicystic dysplastic kidney; GR, grade.

*The associated intraspinal abnormality is a tethered cord.

${ }^{\dagger}$ The associated intraspinal abnormality is a lipomeningomyelocele with tethered cord.

Table 4. Associations between Sacral Cutaneous Lesions and Intraspinal/Urogenital Abnormalities

\begin{tabular}{|c|c|c|c|c|c|c|}
\hline \multirow{2}{*}{ Sacral cutaneous lesion } & \multicolumn{3}{|c|}{ Intraspinal abnormalities } & \multicolumn{3}{|c|}{ Urogenital abnormalities } \\
\hline & OR & $95 \% \mathrm{CI}$ & $P$-value & OR & $95 \% \mathrm{CI}$ & $P$-value \\
\hline Dimple & 0.32 & $(0.13-0.77)$ & 0.012 & 0.20 & $(0.10-0.41)$ & 0.000 \\
\hline Dimple+Hair & 1.03 & $(0.24-4.49)$ & 0.964 & 3.24 & $(1.37-7.66)$ & 0.007 \\
\hline Dimple+DGF & 2.27 & $(0.29-18.04)$ & 0.438 & 8.88 & $(2.35-33.65)$ & 0.001 \\
\hline
\end{tabular}

Abbreviations: OR, odds ratio; CI, confidence interval; DGF, deviated gluteal fold.

요로계 이상 동반은 피부 함몰만 있는 군에 비해 피부 함몰과 털이 동반되어 있는 군(교차비 3.24; $95 \%$ 신뢰구간 1.37-7.66; $P=0.007$ ), 피부 함몰과 둔근 주름의 만곡이 동반되어 있는 군(교 차비 8.88; $95 \%$ 신뢰구간 2.35-33.65; $P=0.001$ )에서 높게 나타났 다(Table 4). 수신증이 관찰된 환자 78명 중 46명에서 추적 초음 파 검사를 시행하였고 17 명(37.0\%)은 수신증이 호전되었으나 29명(63.0\%)은 수신증이 지속되었다. 수신증이 호전된 환자들의 추적검사시 연령은 생후 12 개월 이내에 호전된 경우 16 명, 12 개 월 이후에 호전된 경우 1 명으로 가장 늦은 나이에 호전된 경우는 생후 14 개월이었다.

\section{고찰}

천골부의 피부 병변은 일반적으로 정상 신생아의 3-5\%에서 나타나지만, 잠재 척추 파열증 같은 중추 신경계 기형과 동반되어 있을 가능성이 있다,10,11). 이전 연구들을 살펴보면 잠재 척추 파 열증이 있는 영아의 50-100\%에서 천골부 피부 병변이 관찰되는 데 특히 신생아기에는 이상 증상들이 잘 나타나지 않으므로 이러 한 피부 병변이 커다란 진단적 가치를 가진다고 보고하고 있다
4,5,10-13)

피부 병변에 동반되는 척수 이상 중에서 흔히 발견된 계류 척수 는 신경관 발달과정 중 두꺼운 척수 종말근이 퇴화되지 않고 지 속되어 척수 원추를 L2 이하로 잡아당겨 고정시킨 것을 말하며 주로 척추 갈림증과 연관되어 있고 낮은 척수 원추가 특징이다. 척수보다 척추뼈의 성장속도가 상대적으로 빠르기 때문에 척수 에 과도한 장력이 가해져서 정상적인 혈액공급이 되지 않아 척수 허혈이 진행되고 요실금 같은 방광기능장애, 장 기능장애, 허리와 다리 통증, 하지의 비대칭 성장, 발 변형, 하지 근력약화 및 감각변 화, 진행성 척추 측만증 등 다양한 신경학적 증상과 징후가 나타 나게 된다 ${ }^{3-5)}$. 임상 증상은 다양하게 나타나고 성인기까지 지연될 수도 있으므로 증상이 없는 영아는 주기적으로 신경학적 검사와 요로계 기능을 평가해야 하며 신경학적 징후가 발생할 경우 수술 적 치료를 해야 한다 ${ }^{5}$.

지금까지의 연구에서는, 단일 병변에서보다 복합 병변에서 척 수 이상 소견이 증가한다고 보고되고 있다. 또한 털, 피부색 변화, 피부 종괴 등과 같은 병변이 동반되어 있지 않은 피부 함몰만 관 찰될 때에는 잠재 척추 파열증이 있을 가능성이 낮아서 선별검사 를 시행하지 않아도 된다고 보고하고 있다 ${ }^{4,12-19)}$. 본 연구에서도 복합 피부 병변에서 척수 이상 소견의 가능성이 높게 나타났으나 


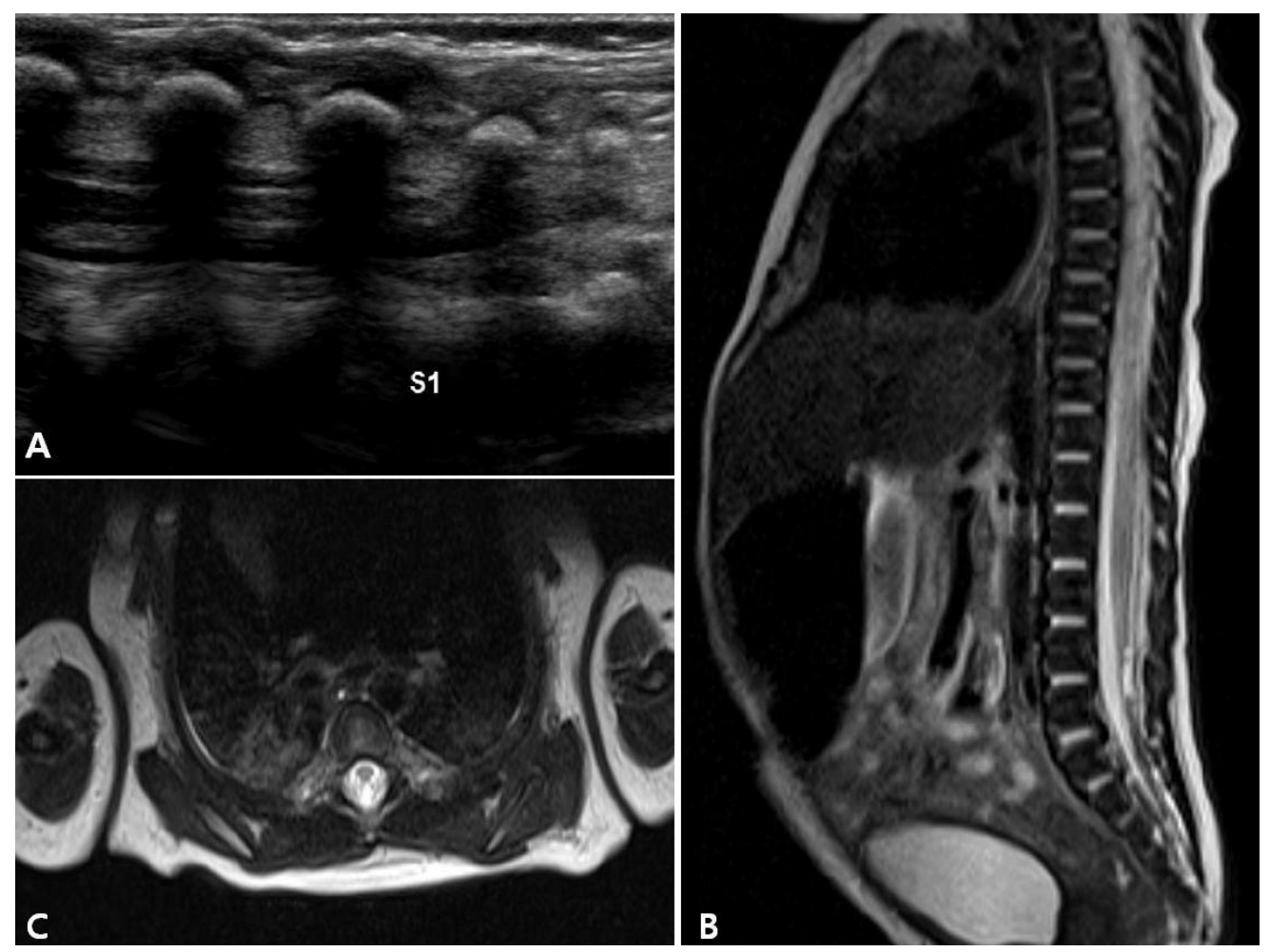

Figure 2. A 2-day old infant with sacral dimple. (A) Sagittal ultrasonography showing low-lying conus medullaris tip down to L5/S1 disc level. (B) Sagittal MRI demonstrating low-lying conus medullaris tip down to L4 lower body level, suggesting tethered cord syndrome. (C) Axial MRI demonstrating the conus medullaris tip which is opened and attached to the posterior dural sac.

의미 있는 차이는 없었고(교차비 2.18; $P=0.129$ ), 피부 함몰만 있 는 경우 척수 이상 소견의 가능성은 의미 있게 낮았다(교차비 $0.32 ; 95 \%$ 신뢰구간 $0.13-0.77 ; P=0.012)$. 그러나 단순 피부 함몰 만 있는 환자에서도 드물게 신경학적 문제를 일으킬 수 있는 계 류 척수(8명; Figure 2), 지방척수수막류(1명) 등의 질환이 발견 되었다. 그러므로 천골부 피부 병변이 관찰되는 영아에서는 동반 된 신경계 질환을 확인하기 위해서는 선별검사로서 천골부 초음 파 검사 시행을 고려해야 할 것이라 생각한다.

진단 방법으로는 신경학적 검사를 포함한 신체 검진, 척추 단순 방사선촬영, 척추 컴퓨터 단층촬영 이외에 초음파 검사와 MRI가 있다. 초음파 검사는 경제적이고 방사선 노출에 대한 부담이 없으 며 검사 시간이 상대적으로 짧고 검사시 진정이 필요하지 않은 안전한 검사 방법이다. 척수와 그 주위에 근접해 있는 요천골부 신경 뿌리의 움직임까지도 관찰할 수 있다는 장점으로 인해 천골 부 피부 병변에 대한 선별검사 방법으로 초음파 검사를 시행하고 있다3-5,14,20,21). 그러나 보통 생후 3개월 이후에는 하부 척추의 뒤 쪽 부분에 골화가 진행되어 비정상적인 척수의 위치 확인이 어려 워지므로, 초음파 검사는 생후 3개월 내에 시행하는 것이 적절하 다고 권장되고 있다 $3,5,14,22)$ MRI는 방사선 노출에 대한 부담이 없 고 연조직을 확인하기 좋은 장점으로 인해 가장 좋은 확진 방법
이지만, 비싼 비용과 검사시 진정이 필요하다는 단점이 있다4,13). Medina 등 ${ }^{11)}$ 의 연구에서는 천골부에 두 가지 이상의 피부 병변이 관찰되는 경우, 또는 요로계 기형이나 소화기계 기형 등이 동반되 는 등 잠재 척추 파열증이 있을 가능성이 높다고 판단되는 경우 에는 초음파 검사 대신 MRI를 먼저 시행하는 것이 비용절감 측면 에서 더 좋다고 보고하고 있다.

본 연구에서 천골부 초음파 검사상 종말 뇌실과 척수 종말근 낭 종은 대상 환자의 $21.7 \%$ 에서 나타났는데 이들은 정상변형으로 볼 수 있다. 종말 뇌실은 태생 3주경부터 진행되는 신경관 형성 과정 중 2 차 신경관형성시기에 퇴화되지 않고 남아있는 척수 원 추의 일부분이며7,8,23,24), 척수 종말근 낭종도 배아기 잔존물이라 고 추측되지만 아직까지 정확한 기원과 타당성에 대해서 밝혀진 바는 없다8,9) Irani 등8)과 Lowe 등9)은 다른 기형이 동반되지 않고 종말끈 낭종만 있는 경우에는 추가 검사가 필요하지 않다고 보고 하고 있다. 하지만 척수구멍증(syringomyelia), 척수내수종 등과 같은 이상 병변을 척수 종말끈 낭종으로 잘못 진단할 수 있으므 로 엄격한 기준 즉, 척수 원추 말단보다 아래에 있는 종말끈의 한 가운데에 위치한 방추형의 격막으로 분리되어 있는 저음영의 단 순 낭종이라는 기준을 따라야 한다 ${ }^{8,9)}$. 만일 이상 병변과의 감별 이 어려운 경우에는 MRI를 시행하는 것이 좋을 것이라 생각한다. 
잠재 척추 파열증에서 동반되는 요로계 질환으로는 요실금 같 은 방광 기능 이상과 수신증, 방광요관 역류 등의 기형이 있는데, 이들은 일반적인 경우에서보다 더 높은 빈도로 나타난다. 진단 및 치료가 지연될 경우 요로계의 기능적 폐쇄, 반복적인 요로감염, 수신증의 악화, 신기능 저하, 신부전 등이 발생할 수 있다2.5). 따라 서 이러한 이상을 조기에 확인하기 위해서 생후 3개월동안 소변 검사, 신기능 평가, 복부 초음파 검사 등을 하는 것이 권장되고 있 다5).

본 연구에서는 복부초음파검사를 시행한 317명 중 86명 (27.1 $\%)$ 에서 이상 소견이 나타났고, 이들 중 수신증만 관찰된 경우는 78 명 (24.6\%)이었다. 산전초음파 검사 소견과 비교했을 때 317명 중 산전초음파 검사상 이상 소견이 없었던 경우는 255 명, 이상 소 견이 있었던 경우는 36 명, 검사를 안 받았거나 확실하지 않은 경 우는 26명이었다. 이상 소견이 없었던 255명 중 65명에서 요로계 이상이 발견되었고 이중 60명 (23.5\%)이 수신증이었다. 이상소견 이 있었던 36명 중 요로계 이상은 11명(30.5\%)이었고 나머지 25 명은 양수과소증/과다증, 자궁내 성장지연 등의 이상 소견이었 다. 선천성 수신증은 산전 초음파 검사의 발달로 발견하는 빈도가 증가하였는데, 산전 초음파검사상 태아의 약 $2.3 \%$ 에서 발견되고 25-29) 대부분 출생 후 첫 1년 이내에 자연 소실되는 것으로 보고되 고 있다27,28). 이러한 일반적인 발생빈도와 비교할 때 천골부 피부 병변을 가진 영아에서는 훨씬 높은 빈도로 수신증이 나타남을 알 수 있다. 수신증 78명 중 46명을 추적관찰한 결과 17명(37.0\%)에 서 생후 14 개월까지 소실되었으며 이는 $\operatorname{Lim}$ 등 30$)$ 이 보고한 자연 소실율 $29.5 \%$ 과 큰 차이는 없었는데 수신증 등급에 따른 경과관 찰이 필요할 것으로 생각된다.

일반적으로 수신증에 대한 초음파 검사는 생후 24-48시간 이 내에는 낮은 사구체 여과율과 핍뇨로 인해 가음성 결과가 나올 수 있으므로 생리적 핍뇨가 사라지는 생후 3일 이후에 시행하는 것이 좋다고 알려져 있다26,29-31). 하지만 Docimo와 Silver ${ }^{32)}$ 는 생 후 48시간 내에 복부 초음파 검사상 수신증이 없거나 경증의 수 신증이 관찰된 환자들에서 추적 검사를 시행한 결과 생후 1 년 이 내에 다른 폐색성 요로 병변이 발생하지 않았으므로 초음파 검사 를 일찍 시행하는 것이 금기는 아니라고 보고하고 있다. 본 연구 에서 수신증만 관찰된 환자 78 명 중 생후 3 일 이내에 초음파 검사 를 시행한 경우가 30 명 $38.5 \%$ )으로 이 중 20명을 추적 검사한 결 과 16 명에서 수신증이 지속되었으며 새로운 폐색성 병변이 발생 하지는 않았다.

다른 요로계 기형으로는 우측 신장 중복 2 명, 양측 방광요관역 류(grade 5/4) 1명, 마제신 2명, 다낭 형성 이상 신장 1명, 신장 낭 종 2 명이 있었다. 피부 병변별로 비교해 보았을 때 단순 피부 함 몰만 있는 경우에 비해 피부 함몰과 털이 동반된 경우(교차비 3.24)와 피부 함몰과 둔근 주름의 만곡이 동반된 경우(교차비
8.88)는 요로계 기형이 동반될 가능성이 높았다. 또한 수신증을 포함한 요로계 질환이 있는 86명의 환자 중 10명(11.6\%)에서는 천골부 초음파 검사상 척수 이상 소견이 동반되었는데 척수 낭종, 낮은 위치의 척수 원추, 계류척수와 지방척수수막류가 관찰되었 다. Tarcan 등22)은 하부 요로계 기능 이상이 있으나 정상적인 신 경학적 발달을 하고 있는 아이들을 대상으로 천골부 피부 병변과 잠재 척추 파열증과의 연관성에 대한 연구에서, 하부 요로계 기능 이상이 있는 환자의 $31 \%$ 에서 천골부 피부 병변이 동반되어 있었 고 이 중 $36 \%$ 에서 MRI상 계류 척수 등의 잠재 척추 파열증이 발 견되었다고 보고하고 있다. 그러므로 천골부에 피부 병변이 관찰 되는 환자에서 요로계 질환 동반 여부를 확인하기 위해 복부 초 음파 검사를 병행해야 될 것으로 생각한다.

본 연구는 단일 기관의 후향적 연구로 천골부 피부 병변에 대한 구체적인 정보를 얻기에 제한이 있고 각 초음파 검사상 이상 소 견이 관찰되었을 때 추적 검사를 시행한 경우가 $50 \%$ 정도였다는 제한점이 있다. 결론적으로 본 연구에서 천골부 피부 함몰만 있는 경우에도 잠재 척추 파열증이 동반되어 있을 수 있으므로 선별검 사가 필요하며, 특히 털 또는 둔근 주름의 만곡이 동반된 고위험 병변인 경우는 수신증 등 동반될 수 있는 요로계 기형을 확인하 기 위해 복부 초음파 검사가 필요하다고 생각한다. 앞으로 천골부 피부 병변과 수신증 및 다른 요로계 질환의 연관성에 대해서 많 은 연구가 필요할 것으로 생각된다.

\section{REFERENCES}

1) Kinsman SL, Johnston MV. Congenital anomalies of the central nervous system. In: Kliegman RM, Stanton BF, St. Geme JW, Schor NF, Behrman RE. Nelson textbook of pediatrics. 19th ed. Philadelphia: Saunders Elsevier, 2012:1998.

2) Netto JM, Bastos AN, Figueiredo AA, Perez LM. Spinal dysraphism: a neurosurgical review for the urologist. Rev Urol 2009;11:71-81.

3) Kriss VM, Kriss TC, Desai NS, Warf BC. Occult spinal dysraphism in the infant. Clin Pediatr (Phila) 1995;34:650-4.

4) Kriss VM, Desai NS. Occult spinal dysraphism in neonates: assessment of high-risk cutaneous stigmata on sonography. Am J Roentgenol 1998;171:1687-92.

5) Cornette L, Verpoorten C, Lagae L, Plets C, Van Calenbergh F, Casaer P. Closed spinal dysraphism: a review on diagnosis and treatment in infancy. Eur J Paediatr Neurol 1998;2:179-85.

6) Amarante MA, Shrensel JA, Tomei KL, Carmel PW, Gandhi CD. Management of urological dysfunction in pediatric patients with spinal dysraphism: review of the literature. Neurosurg Focus 2012;33:E4.

7) Kriss VM, Kriss TC, Babcock DS. The ventriculus terminalis of 
the spinal cord in the neonate: a normal variant on sonography. Am J Roentgenol 1995;165:1491-3.

8) Irani $\mathrm{N}$, Goud AR, Lowe LH. Isolated filar cyst on lumbar spine sonography in infants: a case-control study. Pediatr Radiol 2006;36:1283-8.

9) Lowe LH, Johanek AJ, Moore CW. Sonography of the neonatal spine: part 1, Normal anatomy, imaging pitfalls, and variations that may simulate disorders. Am J Roentgenol 2007;188: 733-8.

10) Sasani M, Asghari B, Asghari $Y$, Afsharian R, Ozer AF. Correlation of cutaneous lesions with clinical radiological and urodynamic findings in the prognosis of underlying spinal dysraphism disorders. Pediatr Neurosurg 2008;44:360-70.

11) Medina LS, Crone K, Kuntz KM. Newborns with suspected occult spinal dysraphism: a cost-effectiveness analysis of diagnostic strategies. Pediatrics 2001;108:E101.

12) Schropp C, Sörensen N, Collmann H, Krauss J. Cutaneous lesions in occult spinal dysraphism-correlation with intraspinal findings. Childs Nerv Syst 2006;22:125-31.

13) Guggisberg D, Hadj-Rabia S, Viney C, Bodemer C, Brunelle F, Zerah $\mathrm{M}$, et al. Skin markers of occult spinal dysraphism in children: a review of 54 cases. Arch Dermatol 2004;140:110915.

14) Robinson AJ, Russell S, Rimmer S. The value of ultrasonic examination of the lumbar spine in infants with specific reference to cutaneous markers of occult spinal dysraphism. Clin Radiol 2005;60:72-7.

15) Gibson PJ, Britton J, Hall DM, Hill CR. Lumbosacral skin markers and identification of occult spinal dysraphism in neonates. Acta Paediatr 1995;84:208-9.

16) McGovern M, Mulligan S, Carney O, Wall D, Moylett E. Ultrasound investigation of sacral dimples and other stigmata of spinal dysraphism. Arch Dis Child 2013;98:784-6.

17) Lee ACW, Kwong NS, Wong YC. Management of sacral dimples detected on routine newborn examination: a case series and review. HKJ Paediatr 2007;12:93-5.

18) Ben-Sira L, Ponger P, Miller E, Beni-Adani L, Constantini S. Low-risk lumbar skin stigmata in infants: the role of ultrasound screening. J Pediatr 2009;155:864-9.

19) Ponger P, Ben-Sira L, Beni-Adani L, Steinbok P, Constantini S. International survey on the management of skin stigmata and suspected tethered cord. Childs Nerv Syst 2010;26:1719-25.

20) Henriques JG, Pianetti G, Henriques KS, Costa P, Gusmão S. Minor skin lesions as markers of occult spinal dysraphismsprospective study. Surg Neurol 2005;63 Suppl 1:8-12.

21) Hughes JA, De Bruyn R, Patel K, Thompson D. Evaluation of spinal ultrasound in spinal dysraphism. Clin Radiol 2003;58: 227-33.

22) Tarcan T, Tinay I, Temiz Y, Alpay H, Ozek M, Simsek F. The value of sacral skin lesions in predicting occult spinal dysraphism in children with voiding dysfunction and normal neurological examination. J Pediatr Urol 2012;8:55-8.

23) Kriss VM, Kriss TC, Coleman RC. Sonographic appearance of the ventriculus terminalis cyst in the neonatal spinal cord. J Ultrasound Med 2000;19:207-9.

24) Sigal R, Denys A, Halimi P, Shapeero L, Doyon D, Boudghène F. Ventriculus terminalis of the conus medullaris: MR imaging in four patients with congenital dilatation. Am J Neuroradiol 1991;12:733-7.

25) Sairam S, Al-Habib A, Sasson S, Thilaganathan B. Natural history of fetal hydronephrosis diagnosed on mid-trimester ultrasound. Ultrasound Obstet Gynecol 2001;17:191-6.

26) Aksu N, Yavaşcan Ő, Kangın M, Kara OD, Aydın Y, Erdoğan H, et al. Postnatal management of infants with antenatally detected hydronephrosis. Pediatr Nephrol 2005;20:1253-9.

27) Choi SM, Jung JH, Hyun JS, Chung KH. Clinical course of prenatally-detected hydronephrosis: focus on ureteropelvic junction obstruction. Korean J Urol 2008;49:1125-30.

28) Kwak NH, Han SW, Jung JM, Jeon GW, Sin JB. Associated malformations and chromosomal defects in antenatally diagnosed hydronephrosis. Korean J Perinatol 2009;20:354-60.

29) Park YJ, Mun SJ, Bae CW, Lee BH, Kim JI. Post-natal outcome of fetal hydronephrosis detected with prenatal ultrasonography. Korean J Pediatr 2002;45:1213-8.

30) Lim DJ, Park JY, Kim JH, Paick SH, Oh SJ, Choi H. Clinical characteristics and outcome of hydronephrosis detected by prenatal ultrasonography. J Korean Med Sci 2003;18:859-62.

31) Yiee J, Wilcox D. Management of fetal hydronephrosis. Pediatr Nephrol 2008;23:347-53.

32) Docimo SG, Silver RI. Renal ultrasonography in newborns with prenatally detected hydronephrosis: why wait? J Urol 1997;157:1387-9. 